Federal UNIVERSITY
OF CEARÁ
ISSN 1678-2089

\title{
Liabilities and contingencies of Brazilian football clubs
}

\section{Passivos e contingências dos clubes de futebol brasileiros \\ Pasivos y contingencias de los clubes de fútbol brasileños}

https://doi.org/10.19094/contextus.2021.71172 do

\section{Monique Cristiane de Oliveira}

https://orcid.org/0000-0002-6740-9017 (D) $\mathrm{PhD}$ student in Accounting in Federal University of Santa Catarina (PPGC/UFSC) Master's degree in Accounting from Federal University of Santa Catarina (PPGC/UFSC)

monique_bona@hotmail.com

\section{José Alonso Borba}

https://orcid.org/0000-0001-6068-342X (1) Professor at the Federal University of Santa Catarina (UFSC)

Post-Doctorate in Accounting from the University of São Paulo (USP)

j.alonso@ufsc.br

\section{ABSTRACT}

This study aims to identify the characteristics of liabilities and contingencies of 20 clubs participating in the First and Second Division of the Brazilian Championship of 2017 that presented all financial statements from 2010 to 2018. It was found that 79 of 180 balance sheets analyzed presented uncovered liabilities and denoting effective problems of economic and financial unviability although no clubs broke effectively. The findings demonstrate that clubs cannot support themselves and eventually need to raise third-party resources. The study differs from previous research because it identifies the characteristics of liabilities, and provisions as present and future obligations for Brazilian football clubs. Thus, this research contributes by providing an overview of the indebtedness of Brazilian football clubs.

Keywords: contingencies; football; liabilities; provisions; obligations.

\section{RESUMO}

Este estudo busca identificar as características dos passivos e contingências dos 20 clubes das séries A e B do Campeonato Brasileiro de 2017 que apresentaram as demonstrações contábeis de 2010 a 2018. Foi verificado que dos 180 balanços analisados, 79 apresentaram passivo a descoberto denotando problemas efetivos de inviabilidade econômico-financeira embora nenhum clube tenha quebrado efetivamente. Os achados demonstram que os clubes não conseguem se sustentar com recursos próprios e necessitam, eventualmente, captar recursos com terceiros. O estudo se diferencia de pesquisas anteriores porque identifica as características das obrigações presentes e futuras dos clubes de futebol brasileiros.

Palavras-chave: contingências; futebol; passivos; provisões; obrigações.

\section{RESUMEN}

Este estudio busca identificar las características de los pasivos y contingencias de los 20 clubes de las series A y B del Campeonato Brasileño 2017 que presentaron los estados financieros de 2010 a 2018. Se encontró que, de los 180 balances analizados, 79 tenían pasivos no garantizados que denotan problemas reales de inviabilidad económica y financiera, aunque ningún club se ha derrumbado efectivamente. Los hallazgos demuestran que los clubes no pueden mantenerse a sí mismos con sus propios recursos y necesitan recaudar fondos de terceros. El estudio se diferencia de investigaciones anteriores porque identifica las características de las obligaciones presentes y futuras de los clubes de fútbol brasileños.

Palabras clave: contingencias; fútbol; pasivo; provisiones; obligaciones.

\section{Article Information}

Uploaded on 05 June 2021

Final version on 16 August 2021

Accepted on 27 September 2021

Published online on 01 November 2021

Interinstitutional Scientific Committee Editor-in-chief: Diego de Queiroz Machado Associated Editor: Gabriel Moreira Campos Evaluation by the double blind review system (SEER / OJS - version 3)

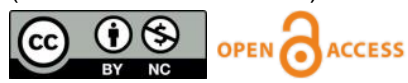

How to cite this article:

Oliveira, M. C., \& Borba, J. A. (2021). Liabilities and contingencies of Brazilian football clubs. Contextus - Contemporary Journal of Economics and Management, 19(22), 330-344. https://doi.org/10.19094/contextus.2021.71172 
1 INTRODUCTION

Debts in professional sports is increasingly common, especially in football clubs. Club indebtedness has gained attention due to the increase in debts to cover short-term obligations and constraints associated with this situation such as poor performance, loosing fans and sponsors, less chances of winning tournaments, consequently, reducing revenues and the liquidity capacity (Mourão, 2012). In Brazil, the economic scenario of football is worrisome. In 2014 the Brazilian clubs' debts exceeded $R \$ 6$ billion (Mattos, 2014; Pamplona, 2015), and the obligations with social security charges of the clubs that participated in First Division of the Brazilian Championship of 2008 exceeded $\mathrm{R} \$ 150$ million (Rezende \& Dalmácio, 2015). Between 2010 and 2013 the average indebtedness rate was $100 \%$ for 33 clubs (Dantas et al., 2017), while between 2012 and 2016 the consolidated indebtedness of Brazilian clubs increased by $28 \%$ (Ambrósio et al., 2017).

Furthermore, the importance given to the subject is still seen in the media. Reports such as Cassucci (2020), Fagiolo (2020) and GloboEsporte.com (2020) address the debt size of Brazilian teams by checking some of the balance sheets published for the 2019 financial year. In some cases, they point to growth or compare them with revenues, as is the case of Sport, which has $R \$ 145$ million to be paid in 2020 but estimates a net revenue of $R \$ 61$ million. In addition, the clubs in the First Division in 2017 and the Sport Club Internacional accumulated together 3,037 lawsuits in labor courts by August 2017, totaling $R \$ 2.4$ billion, representing $38 \%$ of the clubs' total liabilities in 2016 (Mundim, 2017).

There are several justifications for the problem faced by Brazilian clubs. Studies (such as Barajas \& Rodríguez, 2013; Beech et al., 2010; Morrow, 2013; Scelles et al., 2018; Szymanski \& Weimar, 2017) point out that what causes clubs to become financially unsustainable is the excess spending to win championships, as they invest beyond their resources to achieve sporting success, even though this is an uncertain result. Because the uncertainty, sports results may not be achieved and the expectations of resources tied to it may not be realized, impacting the clubs' economic and financial situation (Storm \& Thomsen, 2016), reducing their budget.

González, Fernández, and Suárez (2018) see this situation as a vicious cycle, a greater financial effort is made to improve sports results as opposed to maximizing costbenefit, so the result is an increase in indebtedness. Considering that there is no optimal capital structure that defines the best way for an entity to raise funds (Dantas et al., 2017), and that the level of debt of Brazilian clubs has been increasing over the years, it is important to understand what makes up this debt. Although there is a demand to know about the Brazilian football clubs' debt situation, there are few studies discussing their capital structure, such as the work by Dantas et al. (2017), which observes the need to know the liabilities of the Brazilian clubs. Therefore, this study aims to identify the characteristics of liabilities and contingencies of Brazilian football clubs.

Discussion are increasingly frequent in the Brazilian football scene due to the increase of the clubs' debts (such as Capelo, 2016; Cassucci, 2020; Fagiolo, 2020; Mattos, 2014; Mundim, 2017; Pamplona, 2015). They seek to identify the main points of the clubs' indebtedness and the need to understand this situation. In this sense, this study is justified as an attempt to explain the profile of the obligations, since, when analyzing the liabilities and contingencies of these organizations, it is possible to obtain an overview of the sector, allowing to evaluate the economic and financial situation and to make projections.

Nonetheless, members, fans, investors, governments, and society should be aware of the clubs' indebtedness since this issue represents large money transactions involving taxpayers' money. Recently, the Brazilian bank Caixa Econômica Federal considered the possibility of default of the Sport Club Corinthians Paulista on loan payments regarding the construction of its stadium. The bank assigned an "E" rating to the club in the face of continued contract breaches and discovering that the current cash flow of the club is insufficient to meet its obligations (Garcia et al., 2018). In addition to the execution of club's debt through the attachment of its assets, it is possible that the organization is challenged in court, so that the increase in contingencies can be verified should the situation of default persist. Situations such as these reinforce the importance and necessity of studying their contingencies as they can shape future debts and significantly affect the organizations' financial structure.

In this sense, it is necessary to understand and improve not only the management of Brazilian football, but also to understand how the clubs' debts are formed and managed, since, for the most part, they are unsustainable and capable of deteriorating the value of market and the added value of the football market (Mourão, 2012). Furthermore, it is justified by its focus on showing how the clubs 'debt is structured, pointing out their sources of financing, because, before understanding what determines the teams' indebtedness, it is necessary to understand how it is composed. This fact is what differentiates this study from others (such as Cunha et al., 2017; Dantas et al., 2017; Mourão, 2012).

This study promotes the discussion on football finances, addressing an environment recognized worldwide for the quality of sports practice and marked by economic and financial problems, but still poorly explored academically. Thus, it contributes to filling the gap in the literature, considering that the research focuses on the European context (Barajas \& Rodríguez, 2010, 2013; Beech et al., 2010; Dietl \& Franck, 2007; Dimitropoulos, 2014; Mourão, 2012; Scelles et al., 2018; Szymanski, 2017). In 
Brazil, the sports literature gives greater emphasis on studies on disclosure (Rezende \& Custódio, 2012), efficiency (Dantas et al., 2015, 2016; Dantas \& Boente, 2011), capital structure (P. R. da Cunha et al., 2017) and indebtedness (Brandão, 2012; Dantas et al., 2017), without drawing a profile of the clubs' present and future debts. For the area, the study contributes to provide insights to regulators regarding the formulation of strategies to contain the growth of debts, standards to promote transparency and assist in the disclosure of quality accounting information to all stakeholders.

\section{FOOTBALL DEBT OF FOOTBALL CLUBS}

Debt in professional sports is a problem greatly affecting football clubs, which can be evidenced by the frequent mention of debt increase and consequent financing difficulties. The cause is justified by institutional issues, influence of the media or financial factors. In addition, the indebtedness may originate and increase from the need to raise funds from third parties, funds that end up not being sufficient to cover the clubs' existing debts (Mourão, 2012) or consequences of sports performance.

Behavioral forces such as the media, pressure and high wages affect football club debt. Clubs that increase their debts faster than their incomes become unsustainable and enter a cycle of spending (Dietl \& Franck, 2007). This is reinforced when researchers (such as Rezende \& Dalmácio, 2015 , p. 112) say "the search for better players and, therefore, the hope for better performance has led clubs to serious indebtedness". One of the main factors related to the football clubs' debt is the high salary (and related charges) of players hired to increase the clubs' competitiveness (Barajas \& Rodríguez, 2013; Dantas \& Boente, 2011; Scelles et al., 2018). In addition, for clubs to cope with the business model practiced by most of the football teams, hiring renowned managers is essential. This raises staff costs, leading to debt increase if good resource management is not carried out (Mourão, 2012). When personnel expenses approach club operating income is a sign of poor management (Gutiérrez-Fernández et al., 2017).

Although the level of debt may restrict the availability of cash flows, business managers are led to form a capital structure that maximizes their own interests, without any stakeholder constraints, to the extent that a business is at risk of bankruptcy. When it comes to football clubs, this risk, however, is almost non-existent, because the possibilities to discontinue activities are low due to the various stakeholders who are always able to help in times of crisis. Thus, managers have no restrictions on establishing capital structure (Dimitropoulos, 2014). This situation may create conflicts of interest and increase club debt (Beech et al., 2010), in a context where there is no pressure on managers, profitability is not a goal and monitoring of managerial activities is almost non-existent (Dantas et al., 2017).

Brazilian teams are indebted for different reasons, such as mismanagement and government measures that divide the fiscal debts of clubs in the long term (Brandão, 2012). In addition, activities are not separated according to the football or social departments, which can generate unnecessary debts. This may be one of the reasons why Brazilian football clubs have not yet professionalized management (Mattar, 2014).

The problems affecting the debt payment is the inability to properly predict revenues, as clubs need to deal with the possibility of selling players during the season and the risk of being relegated to an inferior division of the tournaments (Proni \& Zaia, 2014). Therefore, if revenues are not planned sufficiently, the likelihood of delays in debt payments increases. The access-relegation system of European competitions is pointed out by Scelles et al. (2018) as one of the reasons for clubs' high indebtedness. This is the system adopted in some Brazilian football competitions. Alm and Storm (2019) also consider the structure of competitions harmful to clubs, due to the small differences in sports results that can affect the income and planning of the teams.

Debt increase in football clubs can also be explained by other sports variables. Winning clubs tend to have higher debt (Mourão, 2012, Dantas et al., 2017), because in order to win titles and improve image in the media and to increase revenues, the teams invest heavily to hire players, which does not guarantee results and ends up increasing debt.

Studies dealing with the capital structure, debt, liabilities, and contingencies in football clubs are scarce in the Brazilian and international literature. One of them analyzed the explanatory factors of the debt of the main Brazilian football clubs, identifying that for total indebtedness, as fixed assets increase, the percentage of debt reduces, as well as an improvement in the operating result improves in the debt rates. The same was verified for bank debt (Brandão, 2012). Another study identified the factors that affected the debt of Portuguese clubs between seasons $1999 / 00$ to $2005 / 06$. The findings indicate that the higher the value of fixed assets, the greater the debt. The geographic location of the club and the salary costs also negatively influence the debt rate (Mourão, 2012).

The impact of Corporate Governance on the capital structure of 67 European football clubs was evaluated and identified that governance mechanisms such as increased size and independence of boards, and a more fragmented property structure are capable of reducing debt (Dimitropoulos, 2014). Another study showed the explanatory factors of the capital structure of Brazilian football clubs in 2015. The findings identified that the larger the team and the more profitable it is, the lower the debt. The contrary was observed for tangibility (P. R. da Cunha et al., 2017). 
The influence of financial and sports factors on Brazilian football clubs also was verified. For the sample of 33 clubs, they found that as size and profitability increase, indebtedness decreases. The opposite was verified for the relation between debt and total assets. The authors also observed that the fact that a club is in the First Division of the Brazilian Championship and/or one of the 12 largest clubs in Brazil is a preponderant factor for increased debt (Dantas et al., 2017).

The determinants of provisions and contingent liabilities of football clubs in the Serie A of the Brazilian Championship between 2014 and 2017 was studied. As a result, was identified that the size and profitability of the club determine the provisions and contingencies, and how much the larger the club, the higher the amounts of provisions and contingent liabilities. The most profitable clubs, on the other hand, as they assume a lower amount of debt, also have a lower amount of contingencies (B. O. Cunha et al., 2020).

The level of disclosure of provisions and contingent liabilities in Brazilian football clubs was verified between 2014 and 2018 to the top 20 of the CBF club ranking in 2019 who have published their Financial Statements in the period. The results indicate that there is no conformity in the quality of disclosure of provisions and contingent liabilities for most clubs, although this has been improving over the years (Lucena \& Correia, 2019).

This study differs from others because it described and analyzed liabilities of clubs, it includes provisions for contingencies, without focusing on what determines their values or their disclosure, but rather on showing the profile of present and future obligations.

\section{METHODOLOGY}

A sample of 20 football clubs in the First and Second Divisions of the Brazilian Championship of 2017 and that presented the financial statements for the fiscal years 2011 to 2018 were selected.

The financial data were collected in the Balance Sheet for the fiscal years 2010 to 2018 for the sample and updated by the Accumulated Consumer Price Index (IPCA). It is noteworthy that, although the statements were raised from 2011, the year 2010 was used for the analysis because it was presented in the 2011 comparison. In addition, the data were also collected from the most recent balance sheet. For example, from the balance sheet of 2018, the liabilities of 2017 were raised and so on. It is worth mentioning that the same criterion was applied to the explanatory notes. This choice was made due to the verification of re-statements and restatements of balance sheets.

Initially the balance sheets of the clubs were analyzed in relation to their liabilities and provisions. The equity accounts of the liabilities were standardized according to the Accounting Manual for Sports Entities (APFUT, 2017). This unification allowed comparability in the analysis between entities, providing greater understanding of how the bonds are composed. In order to carry out this procedure, the content of the explanatory notes was observed, so when the accounts presented information from several other accounts in the standardized balance sheet, the items were considered separately so that the best reallocation could be made. When the account presented in the balance sheet did not have the respective explanatory note, the amount was allocated according to the relevant amount in the original statement, which in some cases was not clear, requiring arbitration. In addition, at certain times the explanatory note was not clear, creating doubt as to the reallocations, which were made based on own judgment.

As an example, the account "Tax and Labor Obligations" thus presented by many clubs, the note and the values separated according to the definitions of "Taxes and Social Contributions" and "Labor and Social Obligations" proposed by APFUT (2017). It should also be noted that "Revenues to be Appropriated" were found for São Paulo Futebol Clube as asset-reducing accounts from 2011 to 2013, which fit the concepts of "Miscellaneous Advances". Therefore, it was decided to bring these revenues into liabilities, as other clubs do. However, it is noteworthy that the explanatory notes presented by the clubs were often not clear and informative, making it difficult to interpret and reallocate the values in the standardized liability, considered the main limitation in the study.

From the standardization, a qualitative analysis of the data was carried out. First, the number of accounts presented in the original balance sheets was identified. Then, a descriptive statistic was performed to summarize the club's liability data and present an overview of the area in the analyzed period. The objective was to identify the central points of the clubs' debts and their variations in the analyzed period. Also, the composition and evolution of liabilities was verified through vertical and horizontal analyzes together with the indicators of capital structure and indebtedness Table 1, to present a pattern of the clubs' debts and their behavior over the years.

\section{Table 1}

Capital structure and debt indicators used in the analysis.

\begin{tabular}{|c|c|}
\hline Index & Measurement \\
\hline \multirow{2}{*}{$\begin{array}{c}\text { General } \\
\text { Indebtedness } \\
\text { (Gl) }\end{array}$} & Current Liabilities + Noncurrent Liabilities \\
\hline & Total Assets \\
\hline $\begin{array}{c}\text { Short-term } \\
\text { debt }\end{array}$ & Current Liabilities \\
\hline $\begin{array}{l}\text { composition } \\
\text { (STDC) }\end{array}$ & Total Liabilities \\
\hline $\begin{array}{l}\text { Long-term } \\
\text { debt }\end{array}$ & Noncurrent Liabilities \\
\hline $\begin{array}{l}\text { composition } \\
\text { (LTDC) }\end{array}$ & Total Liabilities \\
\hline
\end{tabular}

Source: Dantas et al. (2015).

Note: in percentage. 
Also, the liabilities were divided into financial, fiscal and operational indebtedness, according to a Table 2. About contingencies, in this study, those classified as probable loss were assessed, the provisions, classified as club liabilities were analyzed. It was initially identified whether the clubs declared them in their balance sheets and explanatory notes. From the information provided in the explanatory notes, both provisions and contingencies were classified according to their nature, in (i) tax; (ii) labor; (iii) civil proceedings; and, (iv) others, considering only those that comply with the requirement of recognizing the risk of, respectively, probable and possible loss for the club. When the club did not label this way, the provisions were allocated in a fifth type, unclassified.

Table 2

Financial, fiscal, and operational indebtedness definitions.

\begin{tabular}{|c|c|c|}
\hline Indebtedness & Operationalization & Source \\
\hline Financial & $\begin{array}{l}\text { It consists of the amounts } \\
\text { presented, after } \\
\text { standardization, in the } \\
\text { "Loans" account }\end{array}$ & $\begin{array}{l}\text { Brandão } \\
\text { (2012) and } \\
\text { Mourão } \\
(2012)\end{array}$ \\
\hline Fiscal & $\begin{array}{l}\text { It is composed of the } \\
\text { values presented, after } \\
\text { standardization, in the } \\
\text { account "Taxes and } \\
\text { Social Contributions" and } \\
\text { "Parceled Taxes". }\end{array}$ & $\begin{array}{l}\text { Brandão } \\
\text { (2012) and } \\
\text { Mourão } \\
(2012)\end{array}$ \\
\hline Operational & $\begin{array}{l}\text { It consists of amounts not } \\
\text { classified as financial and } \\
\text { tax indebtedness. }\end{array}$ & $\begin{array}{c}\text { Mourão } \\
\text { (2012) }\end{array}$ \\
\hline
\end{tabular}

Source: Developed by the authors.

A descriptive analysis of the information on the liabilities and provisions for contingencies presented by the clubs was carried out. Descriptive statistics was used to summarize the data and present an overview of the area in the analyzed period to identify the central points of the debts of the clubs and their variations. The composition and evolution of liabilities, provisions and contingencies were verified through vertical and horizontal analyzes in conjunction with capital and debt structure indicators to present a pattern of the debts of the clubs and their behavior over the years.

In relation to provisions, some information was initially identified in the statements, classified as (i) the existence of the account in the balance sheet; (ii) explanatory note; (iii) probability of occurrence; (iv) account movements (additions and write-offs); (v) number of disputes (lawsuits/administrative processes); and (vi) classification of provisions. The main provisions and the frequency with which the clubs present them was verified. Descriptive analysis was performed together with the descriptive statistics about the values.

Considering the evidence from this study on the representativeness of debts for large, insolvent, and southern clubs, to complement these results, a median difference test was carried out to verify whether there are significant differences between the groups' indebtedness. Therefore, the non-parametric Two-sample Wilcoxon ranksum (Mann-Whitney) test was performed, which has the null hypothesis that the distribution of both groups is the same.

To carry out the test, the values of the indicators General Indebtedness, Short and Long-Term Indebtedness and the ratio of provisions for contingencies and total liabilities were considered. The size, solvency and region variables were operationalized as dummies. For large clubs, 1 was attributed to Clube Atlético Mineiro, Botafogo de Futebol e Regatas, Corinthians, Cruzeiro Esporte Clube, Clube de Regatas do Flamengo, Fluminense Football Club, Grêmio Foot-Ball Porto Alegrense, Internacional, Sociedade Esportiva Palmeiras, Santos, São Paulo and Clube de Regatas Vasco da Gama (Dantas et al., 2015) and zero for the others. For solvent clubs, 1 was assigned to clubs with positive equity and zero to those with negative equity (Dantas et al., 2015), because this represents one of the ways to measure insolvency in football (Beech et al., 2010; Szymanski, 2017). Regarding the region, 1 was attributed to clubs in the Southeast region (America Mineiro, Atlético Mineiro, Botafogo, Corinthians, Cruzeiro, Flamengo, Fluminense, Palmeiras, Associação Atlética Ponte Preta, São Paulo, and Vasco) and zero to the others.

\section{ANALYSIS AND DISCUSSION OF RESULTS}

\subsection{Indebtedness of Brazilian Football Clubs}

Analysis of the financial statements of the 20 football clubs resulted in 180 balance sheets for the period between 2010 and 2018, in which 159 liability accounts were identified (current and non-current), resulting in an average of 7.95 accounts per club, re-classified among the 13 accounts proposed by the APFUT.

\subsubsection{Findings on liabilities}

The total average amount of debt presented in each balance sheet was $R \$ 476.23$ million, most of which refers to non-current liabilities, which represent $62.26 \%$ of total debt (Table 3). This finding is different from other studies (such as Cunha et al., 2017), who found that short-term debt represented the larger part of the debt. Criciúma Esporte Clube was the club that disclosed the balance sheet with the lowest amount of current liability ( $R \$ 4,54$ million, 2018), and the balance sheet with the lowest total liability (R\$19,983 million, 2010), in contrast to São Paulo, which presented the highest amount of debt classified as current ( $R \$ 660,19$ million, 2012). As for non-current liabilities, the Esporte Clube Juventude stands out, with the lowest amount of total liabilities ( $R \$ 2,90$ million, 2013) and Corinthians, which disclosed the balance with the largest non-current debt in the period ( $R \$ 1,31$ billion, 2012) and the highest amount of total liabilities ( $R \$ 1,88$ billion, 2012) among the 180 balance sheets analyzed. Consequently, it is the club with the highest average of the period. 
Of the 20 clubs, $50 \%$ have a total average liability of less than $\mathrm{R} \$ 500$ million. Between 2012 and 2015, four clubs - Botafogo (2), Corinthians (5), Flamengo (4) and São Paulo (4) - had total liabilities more than one billion reais. For Corinthians and São Paulo this is due to the high value of "Miscellaneous Advances", while for Botafogo and Flamengo it is a consequence of the high amount of installment taxes. It should be noted that, except for Corinthians, the debt of the other clubs was concentrated in the long term in all years. While at Corinthians, she started to focus on the short term as of 2016, and in 2018 almost $70 \%$ was due until the end of the following year. Such a situation can result in liquidity problems if the club does not have resources to cover liabilities.

Table 3

Descriptive statistics of the liabilities of Brazilian football clubs (2010-2018).

\begin{tabular}{lcccccccc}
\hline & Minimun & $\mathbf{1 Q}$ & Mean & Median & $\mathbf{3 Q}$ & Maximun & Standard Deviation & Obs. \\
\hline Current Liabilities & 4,539 & 36,089 & 179,728 & 180,579 & 275,941 & 660,189 & 139,402 & 180 \\
Noncurrent Liabilities & 2,898 & 53,262 & 296,490 & 235,676 & 478,093 & $1,311,467$ & 265,272 & 180 \\
Total Liability & 19,028 & 89,787 & 476,218 & 488,952 & 703,694 & $1,880,747$ & 386,091 & 180 \\
\hline
\end{tabular}

Source: Developed by the authors.

Note. in thousands of reais.

Growth in general indebtedness (GI) and long-term debt composition (LTDC) indicates an increase in debt in the period, especially in the long term (Figure 1). In addition, liabilities registered as 'long-term' concentrate the highest amounts in relation to total liabilities. It is worth mentioning the two periods (2014 and 2015) in which the total liabilities was higher than the clubs total assets, causing an uncovered liability when all the debts of the 20 clubs were added, 11 of them with an average greater than $100 \%$ in the period. At the beginning of the period, the short and longterm debt was balanced, and from 2014 on, the long-term debt started to have a more relevant proportion. These results are still high over the period and indicate financial problems.

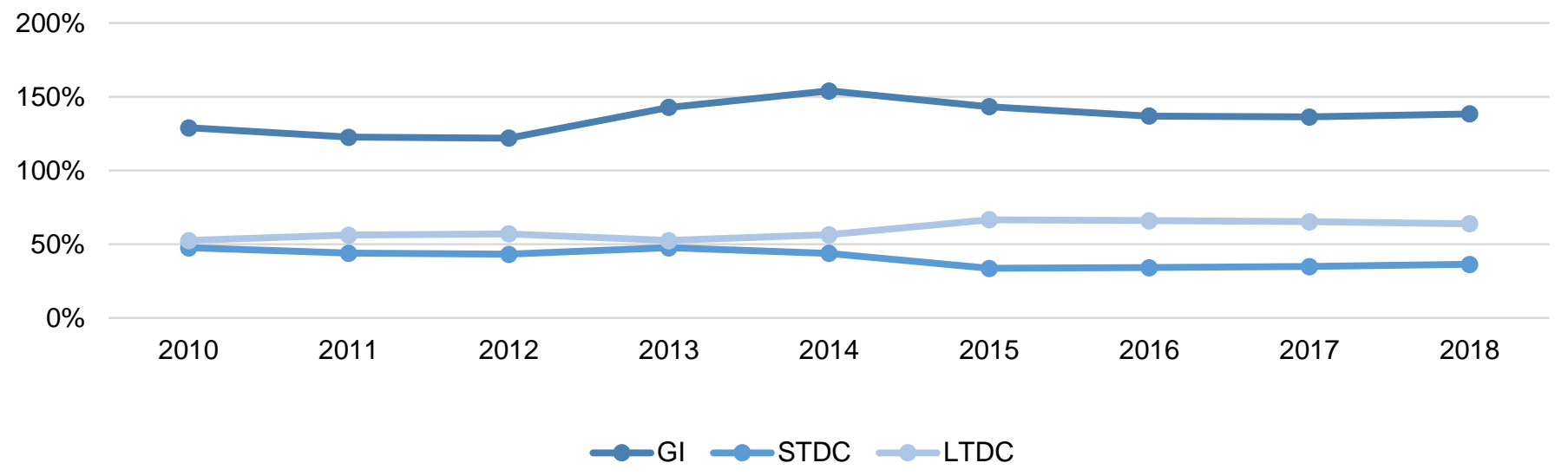

Figure 1. Evolution of average capital structure and debt indicators (2010-2018).

Source: Developed by the authors.

Note. GI - General Indebtedness; STDC - Short-term debt composition; LTDC - Long-term debt composition.

For general indebtedness, the results corroborated other study (as Dantas et al., 2015), who verified between 2010 and 2012 rates close to $100 \%$, indicating, in some cases, the existence of uncovered liabilities, caused mainly by the successive deficits of the clubs (in the period, 102 deficits were observed, representing $64 \%$ of the total of the analyzed statements). Results from the work (such as Dantas et al., 2017) show the same, with clubs presenting liabilities that were superior than their assets over the years. In addition, Brazilian clubs had a similar situation to the Spanish in 2007 and 2008 (Barajas \& Rodríguez, 2010), most of which was financed by third-parties, without being able to generate resources from their own operation or structure.
This type of funding relying on third parties brings great risks, as debt has grown over the years, especially in relation to onerous debts such as loans. Although most debts are non-current, which would be positive due to the longer time to generate funds for settlement, this situation is relevant as the equity has diminished. It can be deduced that the obligations assumed, in general, do not serve as a supplement to equity since internally the clubs have not generated funds with their structure. Thus, there are situations of clubs contracting a debt to settle others, which can lead to financial unsustainability depending on the time for settlement of these obligations.

According to the literature (Myers, 1984), companies prefer domestic financing and, when the outflow is to raise funds with third parties, seek safer debts first. For the 
authors, there is no balance between them, only internal and external financing. However, these findings demonstrate that clubs have opted for external financing and apparently have not sought out safe debts. The findings provide evidence that for these institutions the Pecking Order theory may not apply, corroborating other study (Dantas et al., 2017).

\subsubsection{Current and non-current liability: evolution and composition}

Initially, while there was a growth of liabilities of $30.17 \%$ from 2010 to 2018 , the opposite was identified for equity, which decreased by $87.07 \%$. Although the value of the equity remained positive at the end of the period, three periods with uncovered liabilities were verified, the lowest value found in 2014 (Figure 2).

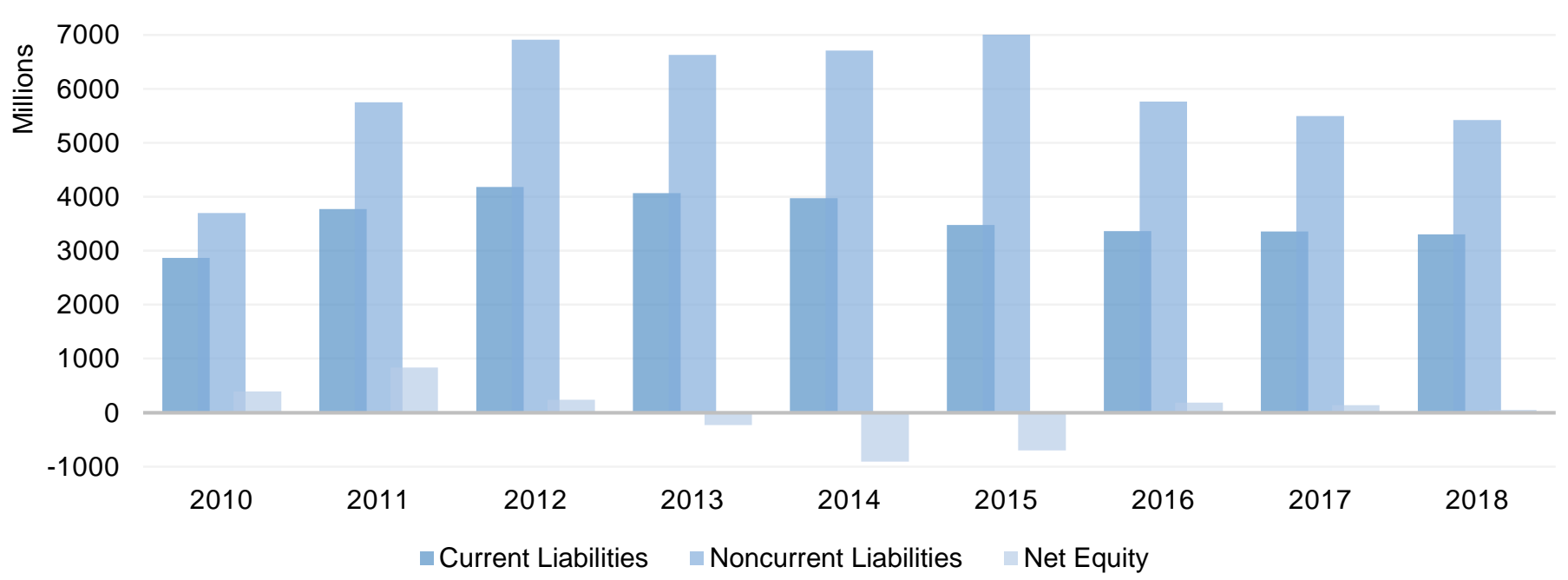

Figure 2. Evolution of liabilities and net worth of Brazilian football clubs (2010-2018)

Source: Developed by the authors.

The considerable increase in the indebtedness of Brazilian clubs is corroborated Brandão (2012) and Dantas et al. (2017) and this phenomenon is not exclusive to Brazil. Was identified (by Barajas \& Rodríguez, 2010; Mourão, 2012) that the Spanish and Portuguese clubs, respectively, spent more than they made in revenues, a similar situation to what was verified in Brazil. Brazilian clubs, especially in 2016, obtained record revenues, but presented a growth in total debts and deficits in their results. This indicates that clubs are being financed more from third party resources than from the revenues generated by their own operation and structure, therefore producing more debt. This situation is corroborates the literature (Cunha et al., 2017; Dantas et al., 2016; Proni \& Zaia, 2014). Other findings (Grafietti et al., 2017) corroborate these results as it was possible to observe, for both samples, that the total value of the liabilities of 2016 remained practically stable.

The study resulted that the values that most impact on the liabilities are "Miscellaneous Advances", "Accounts Payable/Suppliers/Various Creditors", "Loans" and "Taxes in installments", in this order. In addition, they had a participation in total liabilities of more than $10 \%$ at least one of the analyzed years. From 2011 to 2015, the "Miscellaneous Advances" account was the most representative of the club's obligations, without considering "Prepaid Revenues". In 2012, together, they represent for about $35 \%$ of the clubs' liabilities. However, as of 2016 this representativeness reduced to close to $22 \%$ and in 2018 it did not exceed $20 \%$. However, they are values that attract attention in the clubs, because the literature shows that clubs rely mainly on revenues from television broadcasting rights and sponsorships (Costa \& Marinho, 2005; Dantas et al., 2015; Dantas \& Boente, 2011; Gonçalves \& Carvalho, 2006; Rezende \& Custódio, 2012). Thus, the club commits to contracts on broadcasting rights, for example, for future seasons, without even knowing if it will continue to compete for a specific Division or tournament. One of the factors of insolvency pointed out (by Beech et al., 2010) is when clubs are relegated to a lower division and are not able to manage the reduction of revenues in the budget.

In this context, Brazilian clubs usually invest at the beginning of the season to set up competitive teams capable of winning the main competitions they play. However, efficiency is not guaranteed and there is a possibility that at the end of the season the club has not won a title or has been relegated to a lower division. When that happens, the budget for the next season is compromised. Thus, it is understood that the situation of the clubs becomes complicated because they are using future resources to develop their present activities and poor management of resources can jeopardize the execution of these contracts.

The fiscal, financial and operating indebtedness increased for Brazilians, opposite to the Spanish clubs, in which the growth of the fiscal indebtedness and the reduction of the financial was identified (Barajas \& Rodríguez, 2010). In addition, this study detected a $45 \%$ growth in operational growth indebtedness, although it has been decreasing since 2015 (Figure 3). This may indicate 
that, while Europeans sought other sources of funding, Brazilians opted to finance themselves, generally, with loans from banks, raising the debt not only by the principal amount but also by the aggregate interests. It should be noted that despite the growth of debt in the period, which reached the highest value of the historical series in 2012, they have been reducing since then and non-current liabilities are almost reaching the initial value.

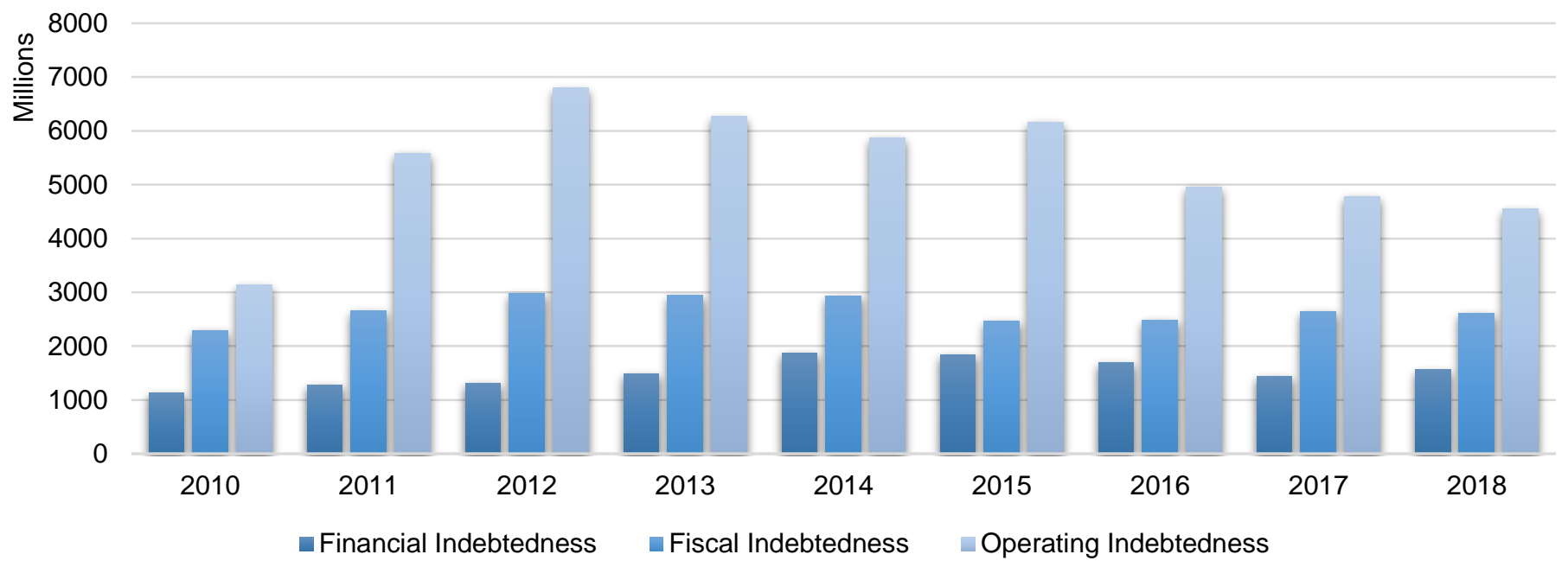

Figure 3. Evolution of club indebtedness (2010-2018).

Source: Developed by the authors.

\subsubsection{Reports on uncovered liabilities}

In the historical analysis, the aggregate liabilities of the 20 teams were higher than the assets in two years (2014 and 2015), denoting a situation of uncovered liabilities.
Between 2010 and 2018, the clubs' equity decreased by $87.59 \%$.

Table 4 shows the total of balance sheets with identified uncovered liabilities.

Table 4

Rate of balance sheets with uncovered liabilities (2010-2018).

\begin{tabular}{lcccccccccc}
\hline & $\mathbf{2 0 1 0}$ & $\mathbf{2 0 1 1}$ & $\mathbf{2 0 1 2}$ & $\mathbf{2 0 1 3}$ & $\mathbf{2 0 1 4}$ & $\mathbf{2 0 1 5}$ & $\mathbf{2 0 1 6}$ & $\mathbf{2 0 1 7}$ & $\mathbf{2 0 1 8}$ & Total \\
\hline Number of Balance Sheets & 20 & 20 & 20 & 20 & 20 & 20 & 20 & 20 & 20 & 180 \\
Number of Negative Equity & 8 & 6 & 7 & 8 & 10 & 11 & 10 & 9 & 10 & 79 \\
\hline Negative Equity & $40 \%$ & $30 \%$ & $35 \%$ & $40 \%$ & $50 \%$ & $55 \%$ & $50 \%$ & $45 \%$ & $50 \%$ & $44 \%$ \\
\hline
\end{tabular}

Source: Developed by the authors.

The number of balance sheets with uncovered liabilities has increased reaching, and in 2015 , one in every two clubs presented deficit. Since 2014 since 2014 the number of clubs in this situation has remained almost the same. There were four clubs that had negative equity values in all years researched (Botafogo, Fluminense, Goiás Esporte Clube and Vasco). On the contrary, América Futebol Clube Minas Gerais, Clube Athletico Paranense, Atlético Mineiro, Criciúma, Internacional and São Paulo, did not have debts higher than their assets in the period. Data show that $70 \%$ of the 20 clubs studied presented a deficit in at least one balance sheet and is a situation also found other studies (Dantas et al., 2015, 2016).

It is noteworthy that the situation of the clubs in Rio de Janeiro is problematic, three out of the four clubs of the sample located in Rio de Janeiro present deficit (Botafogo, Fluminense and Vasco). Studies (such as Brandão, 2012; Proni \& Zaia, 2014) found that four football teams located in Rio de Janeiro were the ones with the largest debts in their studies. Nevertheless, this situation may be directly related to the economic problems faced by the state of Rio de Janeiro.

In general, the high number of clubs reporting uncovered liabilities in their balance sheets is a relevant issue. In some cases, even if all assets of the team were liquidated, they would still not be able to cover all their obligations. Therefore, the situation of the organizations is critical, as they are unsustainable, few of them have prospects for reversing the scenario and measures to change this scenario are not observed.

\subsection{Provisions for contingencies}

Of the 180 balance sheets analyzed, only 13 did not present provisions for contingencies in the period. Cruzeiro did not provide information on the provisions between 2010 and 2016. Although it does not present them, there is a note clarifying that there are no provisions since 2013 as they have no lawsuits considered as possible loss. On the other hand, Avaí Futebol Clube started to do so only from 2013, while América Mineiro and Coritiba Foot Ball Club only did not present them in 2010. Furthermore, only in 2017 did all 
clubs start to present an account entitled "provisions for contingencies".

\subsubsection{Findings on provision for contingencies}

Since 2014, all the clubs in the sample have presented explanatory notes on provisions for contingencies. Of the 180 balance sheets analyzed, 169 had notes and $92 \%$ included provisions for contingencies, of which 90 mentioned that these provisions were based on lawsuits the club considers as probable losses.

Coritiba (since 2014) and Grêmio (all years), presented the information on the number of lawsuits they are part of. The number of lawsuits presented in the balance sheets was of 134 (Grêmio) and 788 (Coritiba), a different number to that reported by Mundim (2017) who presented for the clubs 154 and 128 labor lawsuits, respectively. In addition, the amounts provisioned also differ by Mundim (2017) who showing $R \$ 19.35$ million for Grêmio and $R \$$ 36.71 million for Coritiba, whereas in this work the value was higher for both clubs, based on their explanatory notes.

It was also verified that in 2015 Grêmio presented three administrative processes in the Federal Revenue Agency. In 2016, the club again mentioned these disputes, however, when checking the individual values, there were no administrative obligations in the current or comparative year.

The descriptive statistics of provisions for contingencies are presented in Table 5.

Table 5

Descriptive statistics of provisions for contingencies.

\begin{tabular}{|c|c|c|c|c|c|c|c|c|}
\hline & Minimum & $1 Q$ & Mean & Median & $3 Q$ & Maximum & $\begin{array}{l}\text { Standard } \\
\text { Deviation }\end{array}$ & Obs \\
\hline Labor & 33 & 4,138 & 16,260 & 8,690 & 18,110 & 136,130 & 23,382 & 137 \\
\hline Taxes & 95 & 3,012 & 26,798 & 8,512 & 27,172 & 249,065 & 47,996 & 49 \\
\hline Civil & 21 & 1,387 & 15,954 & 6,351 & 21,846 & 125,927 & 23,457 & 124 \\
\hline Others & 1,579 & 4,648 & 5,168 & 5,704 & 6,367 & 6,790 & 1,745 & 7 \\
\hline Not classified & 0 & 1,751 & 10,202 & 5,466 & 17,706 & 37,055 & 10,730 & 33 \\
\hline Total & 1,219 & 7,688 & 35,280 & 16,370 & 36,194 & 393,200 & 52,415 & 167 \\
\hline
\end{tabular}

Source: Developed by the authors.

Note. In thousands of reais.

It can be observed that during the nine years, 167 mentions of provisions for contingencies were found in the 180 balance sheets analyzed ( $92.78 \%$ ), which generated an average of $R \$ 35,40$ million in provisions per balance sheet. Although presented in greater numbers, labor provisions have a lower average than tax. Botafogo presented the highest amounts of provisions in 2013 and Figueirense Futebol Clube the lowest amounts provisioned in 2011. Botafogo presented the highest amounts of provisions, both tax and labor, both in 2013. According to the news, the club responded in 2017 to lawsuits that accumulated around $R \$$ 200 million (Mundim, 2017).

Figueirense, on the other hand, is responsible for the highest growth in the provisions, 1002\% between 2010 and 2018 , and this situation is due, in sum, to the almost $R \$ 14$ million increases in labor provisions. It should be noted that the club has been facing off-field problems since 2017 when its management was transferred to Elephant, culminating in W.O. due to the lack of payment of salaries and the unilateral termination of the contract between the club and the company (Cardoso, 2019). Such a situation may be an explanation for the massive increase in contingent labor provisions.

The club with the lowest labor provision is América Mineiro (2018) and Palmeiras (2016) represents the lowest amount of tax provisions. Regarding civil and other provisions, the highest values were presented by Flamengo (2012) and Esporte Clube Goiás (2010), while the lowest were by Ponte Preta (2018) and Botafogo (2010), respectively. About the provisions that have not been classified, São Paulo (2018) is responsible for the highest amount. It is noteworthy that not classifying the provisions decreases the transparency of the information and limits the user's knowledge of the types of disputes in which the club is involved.

Another point to highlight is the lower value of provisions that were not classified, presented by América Futebol Clube. This club did not present any changes in additions or reductions in the contingency provisions account in the explanatory notes, and the value remained the same from 2011 to 2014. This situation was also verified for Avaí Futebol Clube, Figueirense, Atlético Mineiro, Flamengo, Fluminense, Goiás, Palmeiras, Ponte Preta and Vasco. The fact that draws attention in these cases is that the provisions remain for a long time without any additional information or update, and it is not possible to determine the causes for this. It is possible that the club has not given updates because it has not monitored the dispute, or it has not undergone any changes over the years. However, the teams do not mention why the provisions have not undergone any changes over the years.

\subsubsection{Provision for contingencies: evolution and composition}

During the nine years studied, it was possible to see that the most frequent was the labor provision, followed by the civil and tributary. This group increased by $62 \%$ in value in the period. A plausible justification is the possibility that 
athletes have, due Art, 31 of the Pelé Law, to enter the labor court requesting the end of the contract, which occurs when salaries are delayed at least three months. In this case, the club receives an order to terminate the contract, but labor costs are still discussed (Kampff, 2019).

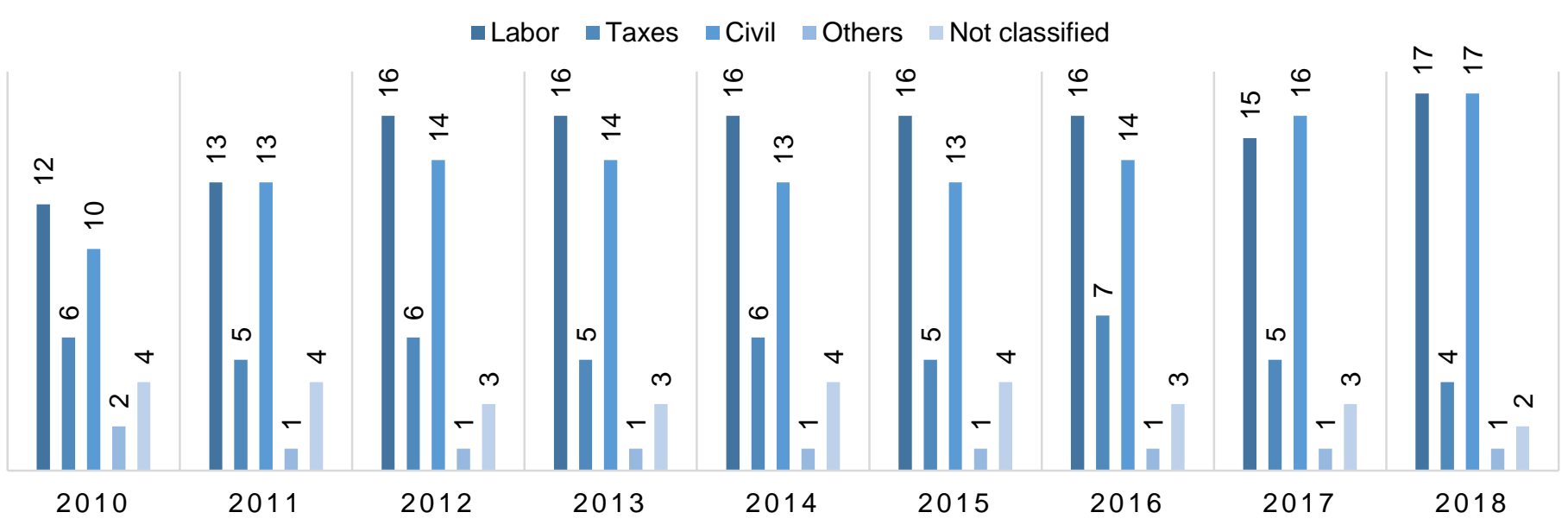

Figure 4. Frequency of presentation of provisions for contingencies.

Source: Developed by the authors.

Labor provisions are presented practically by all the clubs and denote, for the most part, legal obligations related to labor or image rights. In 2018, the updated figures represented $R \$ 360$ million and an increase of $62 \%$ in relation to 2010. Tax provisions have reduced not only in terms of classification, but also in value. This was the type that more reduced in the period, about $57 \%$ compared to 2010. Here, some points should be highlighted. In the analyzed period, there were two specifics governmental installments for the tax debts of the clubs with the Federal Government, Timemania and PROFUT. With this possibility, the clubs assumed obligations with a payment schedule, making them classifiable as "Installments Taxes" and no longer as a provision, for example, because they would correspond to present obligations with a certain amount and term for payments. In addition, in 2018 the Federal Government launched the Special Tax Regularization Program (PERT) to which the clubs also benefited, as shown in the explanatory notes. In other words, the possibility to be raised is that with the installments of Timemania, PERT and PROFUT, the judicial disputes regarding fiscal debts culminated in agreed installments, becoming a de facto obligation. An example of this is observed with Botafogo.

Regarding the classification 'others', there are administrative provisions presented by Goiás, that disclosed them until 2015. However, in 2016 there was no value in this item, nor in the comparison with 2015. The note did not mention the reason for the amount to have been written off, either by loss, change of probability or extinction of the process. However, when comparing the values, it was verified that in 2016 they were classified as related to tax and not as administrative. What is seen, therefore, is the lack of uniformity in the items used, as well as in the
It is noted that, in general, the frequency of mention of the types of provisions has been constant since 2012, mainly the labor ones. Figure 4 shows how often clubs present each type of provision. 
provisions they made. The information presented is generalized so it is not known, in fact, how many processes the clubs are responding to. It was observed that, in some cases, the notes only repeated those drafted in previous years. In addition, errors were often found in the position of the values, since they only appeared to have been pasted and the values of the year to which they refer, updated.

On the other hand, it is important to point out that over the years the clubs have presented more information about the provisions for contingencies. There is greater detail in

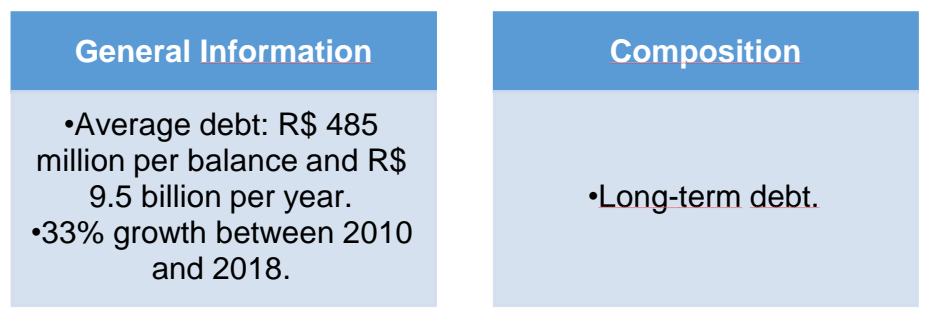

Figure 5. Debt characteristics of Brazilian football clubs.

Source: Developed by the authors.

Figure 5 shows that clubs have raised funds from third parties to pay other debts, which are often overdue and usually come in the form of anticipation of funds. In other words, the teams have advanced amounts to receive, in general, transmission rights, to settle current obligations, compromising future budgets. In addition, there is a relevant growth in indebtedness, being even greater for provisions, especially those arising from labor claims.

Additionally, it was found that the big clubs, those insolvent and those located in the Southeast region have a higher debt. The sports literature points out that in soccer clubs, those considered large tend to have higher indebtedness, although the risk of insolvency is greater for small clubs (Baroncelli \& Lago, 2006; Dantas et al., 2015; Ferri et al., 2017; Hagen \& Cunha, 2019; Plumley et al., 2021). Table 6 presents the results of the Two-sample Wilcoxon rank-sum (Mann-Whitney) test to verify if there are significant differences in the debts of clubs with these characteristics.

\section{Table 6}

Results of Two-sample Wilcoxon rank-sum (Mann-Whitney) test

\begin{tabular}{cccc}
\hline Size & $\begin{array}{c}\text { General } \\
\text { Indebtedness }\end{array}$ & $\begin{array}{c}\text { Short and } \\
\text { long-term debt } \\
\text { composition }\end{array}$ & $\begin{array}{c}\text { Provisions/ } \\
\text { General } \\
\text { Indebtedness }\end{array}$ \\
\hline Solvency & Prob $>|z|=$ & Prob $>|z|=$ & Prob $>|z|=$ \\
Region & 0.2720 & Prob $>|z|=$ & Prob $>|z|=$ \\
& Prob $>|z|=$ & 0.5957 & 0.1992 \\
& 0.0000 & 0.0259 & 0.0000 \\
\hline
\end{tabular}

Source: Developed by the authors.

As $\operatorname{Prob}>Z$ less than 0.05, the results presented in Table 6 indicate that, at a $5 \%$ level of significance, there is a difference between the general indebtedness of large and small clubs, as well as for the proportion of provisions in relation to the total debts. In this sample, no significant relation to the initial years analyzed, which can be observed, for example, by the increase in the number of provisions classified among one of the categories studied. However, this growth in disclosure does not necessarily reflect quality.

\subsection{Indebtedness profile of football clubs in Brazil}

Based on the results, the Figure 5 presents the characteristics of indebtedness and provisions of Brazilian clubs.

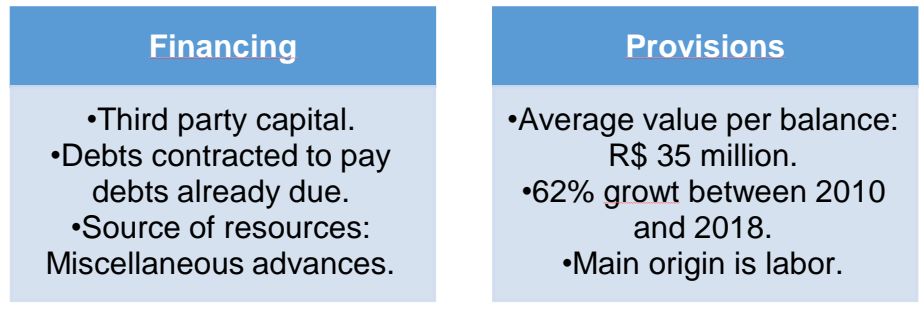

difference was found in the debts of solvent and insolvent clubs, although almost $50 \%$ of the balances presented negative equity in the period. Regarding the region, there are differences between clubs in the Southeast region and the others for all analyzed variables.

These results can indicate that the size of the club and the region where it is located can explain the indebtedness levels of teams in Brazil. However, it is noteworthy that the teams considered as large in this study are located predominantly in the Southeast region, except for Internacional and Grêmio. When looking at the gross values, the debt of big clubs is almost six times greater than that of small ones, reducing to three times when analyzing the region.

\section{CONCLUSIONS}

Given the increase in the debt of Brazilian football clubs and considering that these values may be even higher, since some may not be fully computed in the entities' liabilities, this study aimed to describe the debt profile of Brazilian football clubs. Analysis was carried out on 20 clubs participating in the First and Second Divisions of the Brazilian Championship of 2017, which presented, during the period of 2010 to 2018, the complete set of financial statements.

It was identified that the debt grows over the years, corroborating the studies of Brandão (2012) and Dantas et al. (2017). The results indicate that clubs cannot sustain themselves with their own resources and often need to raise funds from third parties, in the form of loans or government benefits. In addition, it was found beyond the reduction to the net equity, that almost $50 \%$ of the balance sheets analyzed presented a situation of uncovered liabilities. These results indicate that the clubs, for the most part, are increasingly financing themselves with third party resources 
and need alertness, as part depends on attracting costly resources, such as loans and financing.

When compared with data from literature, the indebtedness of Brazilian clubs grew by around $70 \%$ between 2008 and 2018, but the proportion of fiscal debts, which at that date was almost $50 \%$, in 2018 were around $35 \%$. Although, debts with the government have reduced, it is not possible to say that the clubs are paying them, because in 2015, most teams managed to pay in installments and remission part of the debts with the government from PROFUT. Furthermore, the proportion may have been reduced because other obligations such as loans and labor debts may have increased significantly. Thus, it is possible that the Government's own attempt to assist the clubs has not been successful, as was the case with Timemania and pointed out by literature (such as Proni \& Zaia, 2014).

This situation leads to problems of financial balance, with clubs showing high and consecutive deficits. In other companies, if it were continuously presented, they would have declared bankruptcy, which is not the case with clubs. The teams, even in this situation, making new transactions, to make the teams competitive, without worrying about unsustainability that permeates them using more and more third-party resources, entering an unsustainable financial cycle. The conclusion is that in Brazil the football seems to be unsustainable, not the sport, but when it comes to its management. This situation is similar to others presented by football clubs in other countries a few years ago, such as Spain (Barajas \& Rodríguez, 2010). The difficult economic and financial situation of Brazilian clubs is due, in short, to the lack of management and control mechanisms (Rezende \& Dalmácio, 2015).

It is also noteworthy that this study aimed to identify the liabilities of Brazilian football clubs in order to present the indebtedness of these teams, however, other aspects stood out and not only the debt, which is significant, but presented small signs of reduction. First, attention is drawn to the indications of a lack of quality in the structure and presentation of the financial statements. In addition to the disclosure being often in low quality files, there are errors in values and evidence that clubs are just trying to comply with disclosure requirements, without paying attention to issues of reliability, comprehensibility and comparability of the accounting information disclosed. The repetition of values from one year to the next, as it does not happen once in a while and in a few clubs, makes us question the intention of disclosure.

In addition, it was also verified that part of the clubs, subject to PROFUT and, therefore, to the Accounting Manual for Sports Entities, does not adopt the standardized statements according to that manual. In fact, in some clubs, there is no standardization even between one balance sheet and another, which makes understanding and comparisons difficult, so that the standardization performed in this study is reduced, as many values are mixed between the accounts, without proper explanation. complementary via explanatory note. Thus, more than demonstrating how, how much and to whom Brazilian clubs owe, this study contributes to drawing the attention of those responsible for preparing the financial statements of Brazilian clubs, auditors and supervisors to the need for intense monitoring and zeal for data disclosed. Well, credible accounting information can attract investors and assist clubs in their economic and financial restructuring, without spending years depending on government measures.

Based on these results, this study suggests policies that can be adopted to make Brazilian football viable in the long term and mitigate the financial difficulties faced by clubs. First, the redistribution of broadcasting rights in a more equitable and limited a cost-cutting to improve competitiveness and reduce the clubs' financial risk. Second, the establishment of a salary cap, which in Brazil could be related to the division, as it tends to help clubs maintain costs. Finally, those responsible for organizing football should review the financial regulations to provide greater consistency to help clubs achieve long-term financial sustainability (Plumley et al., 2021).

Regarding the limitations, there is a lack of the complete set of financial statements for the period studied, which reduced the sample analyzed and prevented to include a larger number of clubs. Also noteworthy is the lack of clarity in the explanatory notes that often made it difficult to understand the standardization of accounts, as well as bringing subjectivity to judge the reallocation of the explanatory notes in the best possible way. However, although the quality of the information publicized by the clubs is challenged, it is better to study using what is available than being deprived of understanding how the football business works (Barajas \& Rodríguez, 2010).

Finally, the Brazilian football clubs must publish the Financial Statements prepared in accordance with Law no $6.404 / 76$ and other rules issued by the Conselho Federal de Contabilidade since 2003. In addition, since 2015 clubs who joined PROFUT must publish their Financial Statements on their website after being audited and approved by the Fiscal and Deliberative Boards. For the teams who are in the PROFUT, the non-compliance with the publication of the statements and the other provisions of Law $n \circ$. 13.155/15, leeds to club exclusion and with the debt immediately demanded.

\section{REFERENCES}

Alm, J., \& Storm, R. K. (2019). Isomorphic forces and professional soccer standardizations: Instruments of governance for municipal investments? International Journal of Public Administration, 42(3), 185-194. https://doi.org/10.1080/01900692.2017.1422746

Ambrósio, M. A., Daniel, P., \& Aragaki, C. (2017). 10o Valor das marcas dos clubes brasileiros: Finanças dos clubes. BDO RCS Auditores Independentes. www.bdobrazil.com.br

APFUT. (2017). Manual de Contabilidade para entidades esportivas. http://www.esporte.gov.br/arquivos/apfut/Manual/Manual Apfut atual.pdf 
Barajas, Á., \& Rodríguez, P. (2010). Spanish football clubs' finances: Crisis and player salaries. International Journal of Sport Finance, 5, 52-66.

Barajas, Á., \& Rodríguez, P. (2013). Spanish football in need of financial therapy: Cut expenses and inject capital. International Journal of Sport Finance, 9(1), 73-90.

Baroncelli, A., \& Lago, U. (2006). Italian Football. Journal of Sports Economics, $7(1)$, https://doi.org/10.1177/1527002505282863

Beech, J., Horsman, S., \& Magraw, J. (2010). Insolvency events among English football clubs. International Journal of Sports Marketing and Sponsorship, 11(3), 236-249. https://doi.org/10.1108/lJSMS-11-03-2010-B006

Brandão, A. R. (2012). O endividamento dos clubes de futebol no Brasil (Dissertação de mestrado). Universidade Presbiteriana Mackenzie, São Paulo, Brasil.

Capelo, R. (2016). O endividamento da primeira divisão sobe para $R \$ \quad 4,8$ bi - impostos omitidos pesam. https://epoca.globo.com/vida/esporte/noticia/2016/06/oendividamento-da-primeira-divisao-sobe-para-r-48-biimpostos-omitidos-pesam.html

Cardoso, J. L. (2019). Figueirense notifica Elephant e termina contrato com empresa. Diário Catarinense. https://www.nsctotal.com.br/noticias/figueirense-notificaelephant-e-termina-contrato-com-empresa

Cassucci, B. (2020). Dívida do Corinthians dispara e chega a $R \$$ 665 milhões; clube teve déficit recorde em 2019. https://globoesporte.globo.com/futebol/times/corinthians/n oticia/divida-do-corinthians-dispara-e-chega-a-r-665milhoes-clube-teve-deficit-recorde-em-2019.ghtml

Costa, F. L., \& Marinho, E. (2005). Fome de bola: Desafios da gestão esportiva e o futebol no Brasil. Revista Portuguesa e Brasileira de Gestão, 4(1), 42-55.

Cunha, B. O., Machado, L. S., \& Machado, M. R. R. (2020). Provisões e passivos contingentes dos clubes de futebol da primeira divisão do Campeonato Brasileiro: É possível determiná-los? Revista Evidenciação Contábil \& Finanças, 8(2), 133-151. $\quad$ https://doi.org/10.22478/ufpb.2318$\underline{1001.2020 v 8 n 2.47200}$

Cunha, P. R., Santos, C. A., \& Haveroth, J. (2017). Fatores explicativos da política de estrutura de capital dos clubes de futebol brasileiros. PODIUM Sport, Leisure and Tourism Review, 6(1). https://doi.org/10.5585/podium.v6i1.166

Dantas, M. G. S., \& Boente, D. R. (2011). A eficiência financeira e esportiva dos maiores clubes de futebol europeus utilizando de análise envoltória de dados. Revista de Contabilidade e Organizações - RCO, 5(13), 75-90. https://doi.org/10.11606/rco.v5i13.34805

Dantas, M. G. S., Freitas, R. M., Costa, M. A. A., \& Barbosa, A. (2017). The determinants of Brazilian football clubs' debt ratios. Brazilian Business Review, Special Issues, 94-109. https://doi.org/10.15728/edicaoesp.2017.5

Dantas, M. G. S., Macedo, M. Á. S., \& Machado, M. A. V. (2016). Eficiência dos custos operacionais dos clubes de futebol do Brasil. Revista Contabilidade Vista e Revista, 27(2), 113132. https://doi.org/10.14392/asaa.2015080106

Dantas, M. G. S., Machado, M. A. V., \& Macedo, M. A. D. S. (2015). Fatores determinantes da eficiência financeira e esportiva de clubes de futebol do Brasil. Advances in Scientific and Applied Accounting, 8(1), 113-132. https://doi.org/10.14392/asaa.2015080106

Dietl, H. M., \& Franck, E. (2007). Governance failure and financial crisis in German football. Journal of Sports Economics, 8(6), 662-669. https://doi.org/10.1177/1527002506297022

Dimitropoulos, P. (2014). Capital structure and corporate governance of soccer clubs. Management Research Review, 37(7), 658-678. https://doi.org/10.1108/MRR-09$\underline{2012-0207}$
Fagiolo, J. (2020). Auditoria aponta prejuízo acumulado de $R \$$ 15,5 mi da S/A, e Botafogo-SP triplica dívida em 1 ano e meio. https://globoesporte.globo.com/sp/ribeirao-preto-eregiao/futebol/times/botafogo-sp/noticia/auditoria-apontaprejuizo-acumulado-de-r-155-mi-da-sa-e-botafogo-sptriplica-divida-em-1-ano-e-meio.ghtml

Ferri, L., Macchioni, R., Maffei, M., \& Zampella, A. (2017). Financial versus sports performance: The missing link. International Journal of Business and Management, 12(3), 36. https://doi.org/10.5539/ijbm.v12n3p36

Garcia, D., Mattoso, C., \& Fabrini, F. (2018). Avaliação da Caixa vê chance de calote do Corinthians no Itaquerão. http://www1.folha.uol.com.br/esporte/2018/01/1952514avaliacao-da-caixa-ve-chance-de-calote-do-corinthians$\underline{\text { no- }}$

itaquerao.shtml?utm source=newsletter\&utm medium $=e$ mail\&utm campaign=newsfolha

GloboEsporte.com. (2020). Alta dívida a curto prazo gera caos financeiro no Sport; compare caso do clube em ranking da Série

https://globoesporte.globo.com/pe/futebol/times/sport/notic ia/alta-divida-a-curto-prazo-gera-caos-financeiro-no-sportcompare-caso-do-clube-em-ranking-da-serie-a.ghtml

Gonçalves, J. C. D. S., \& Carvalho, C. A. (2006). A mercantilização do futebol brasileiro: Instrumentos, avanços e resistências. Cadernos EBAPE.BR, 4(2), 01-27. https://doi.org/10.1590/S1679-39512006000200003

González, A. M. M., Fernández, F. M., \& Suárez, J. L. F. (2018). Is efficient to play in first division? Influence of promotion and relegation in the technical efficiency of the Spanish professional football teams. Research \& Investigations in Sports Medicine,

https://doi.org/10.31031/rism.2018.02.000547

2(5).

Grafietti, C., Di Caterina, P., Jafet, I. A., Melcher, A. R., Biagio, E. P., Mano, R., Antunes, L., \& Froner, L. S. (2017). Análise econômico-financeira dos clubes de futebol brasileiros $/$ 2017 Dados Financeiros de 2016. https://www.itau.com.br/ arquivosestaticos/itauBBA/conte nts/common/docs/Analise dos Clubes Brasileiros de Fu tebol Itau BBA 2017.pdf

Gutiérrez-Fernández, M., Talavero-álvarez, F. J., \& Coca-pérez, J. L. (2017). Sports management as an emerging economic activity. In M. Peris-Ortiz, J. Álvarez-García, \& M. C. Del Río-Rama (Eds.), Sports Management as an Emerging Economic Activity. Springer International Publishing. https://doi.org/10.1007/978-3-319-63907-9

Hagen, J., \& Cunha, M. N. (2019). The history of investing in football and factors affecting stock price of listed football clubs. International Journal of Financial Management, 9(4), 31-41. https://doi.org/10.13140/RG.2.2.26975.82089

Kampff, A. (2019). Lei garante a jogador com salários atrasados rescisão indireta de contrato. https://leiemcampo.blogosfera.uol.com.br/2019/06/24/leigarante-a-jogador-com-salarios-atrasados-rescisaoindireta-de-contrato/

Lucena, N. M. W., \& Correia, J. J. A. (2019). Evidenciação de provisões e passivos contingentes nos clubes esportivos brasileiros: Análise à luz do CPC 25 e ITG 2003. Revista Gestão e Organizações, 4(1), 1-23.

Mattar, M. F. (2014). Na trave: O que falta para o futebol brasileiro ter uma gestão profissional. Elsevier. https://www.loja.elsevier.com.br/na-trave9788535278675.html

Mattos, R. (2014). Dívidas dos clubes crescem em 2014. Palmeiras tem maior aumento em SP. https://rodrigomattos.blogosfera.uol.com.br/2014/12/12/div idas-dos-clubes-aumentam-em-2014-palmeiras-temmaior-passivo-em-sp/ 
Morrow, S. (2013). Structure and change in professional football: an Old Firm's search for a new market. Soccer and Society, 14(4), 462-484. https://doi.org/10.1080/14660970.2012.753531

Mourão, P. (2012). The indebtedness of Portuguese soccer teams - looking for determinants. Journal of Sports Sciences, $30(10)$, 1025-1035. https://doi.org/10.1080/02640414.2012.685085

Mundim, D. (2017). Peso do atraso: Clubes registram $R \$ 2$ bi em dívidas trabalhistas e $3 \mathrm{mil}$ processos. https://globoesporte.globo.com/futebol/noticia/peso-doatraso-clubes-registram-r-2-bi-em-dividas-trabalhistas-e-3mil-processos.ghtml

Myers, S. C. (1984). The capital structure puzzle. The Journal of Finance, 39(3).

Pamplona, N. (2015). Clubes de futebol devem $R \$$ 6,3 bilhões. http://brasileconomico.ig.com.br/negocios/2015-0505/clubes-de-futebol-devem-r-63-bilhoes.html

Plumley, D., Serbera, J.-P., \& Wilson, R. (2021). Too big to fail? Accounting for predictions of financial distress in English professional football clubs. Journal of Applied Accounting Research, 22(1), 93-113. https://doi.org/10.1108/JAAR-052020-0095

Proni, M. W., \& Zaia, F. H. (2014). Financial condition of Brazilian soccer clubs: An overview. Soccer and Society, 15(1), 108122. https://doi.org/10.1080/14660970.2013.854572

Rezende, A. J., \& Custódio, R. S. (2012). Uma análise da evidenciação dos direitos federativos nas demonstrações contábeis dos clubes de futebol brasileiros. Revista de Educação e Pesquisa em Contabilidade (REPeC), 6(3), 229-245. https://doi.org/10.17524/repec.v6i3.235

Rezende, A. J., \& Dalmácio, F. Z. (2015). Práticas de Governança Corporativa e indicadores de performance dos clubes de futebol: Uma análise das relações estruturais. Contabilidade, Gestão e Governança, 18(3), 105-125.

Scelles, N., Szymanski, S., \& Dermit-Richard, N. (2018). Insolvency in French soccer: The case of payment failure. Journal of Sports Economics, 19(5), 603-624. https://doi.org/10.1177/1527002516674510

Szymanski, S. (2017). Entry into exit: Insolvency in English professional football. Scottish Journal of Political Economy, 64(4), 419-444. https://doi.org/10.1111/sjpe.12134

Szymanski, S., \& Weimar, D. (2017). Insolvencies in professional sports: Evidence from German football. 1-34. https://www.abwl.msm.unidue.de/fileadmin/Dateien/Business Administration/2017 PR Insolvencies.pdf 


\section{CONTEXTUS}

\section{REVISTA CONTEMPORÂNEA DE ECONOMIA E GESTÃO}

CONTEXTUS

CONTEMPORARY JOURNAL OF ECONOMICS AND

MANAGEMENT.

\section{ISSN 1678-2089}

\section{ISSNe 2178-9258}

1. Economics, Administration and Accounting - Journal

2. Federal University of Ceará. Faculty of Economics,

Administration, Actuaries and Accounting

\section{FACULTY OF ECONOMICS, ADMINISTRATION, ACTUARIES} AND ACCOUNTING

University Av. - 2486, Benfica

60020-180, Fortaleza-CE

BOARD: Paulo Rogério Faustino Matos Danielle Augusto Peres

Website: www.periodicos.ufc.br/contextus

E-mail: revistacontextus@ufc.br

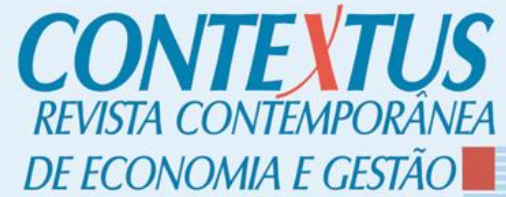

UNIVERSIDADE

FEDERAL

DO CEARÁ

FACULDADE

DE ECONOMIA,

ADMINISTRAÇÃO,

ATUÁRIA

E CONTABILIDADE

\section{Qunals}

DORA

ABEC

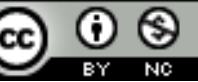

Contextus is classified in the Qualis - Capes system as a B1 journal, in the area of Public and Business Administration, Accounting and Tourism (2013-2016).

Contextus agrees and signs the San Francisco Declaration on Research Assessment (DORA).

Contextus is associated with the Brazilian Association of Scientific Editors.

This work is licensed under a Creative Commons Attribution - NonCommercial 4.0 International license.
EDITOR-IN-CHIEF

Diego de Queiroz Machado (UFC)

\section{ASSISTANT EDITORS}

Alane Siqueira Rocha (UFC)

Márcia Zabdiele Moreira (UFC)

\section{ASSOCIATE EDITORS}

Adriana Rodrigues Silva (IPSantarém, Portugal)

Alessandra de Sá Mello da Costa (PUC-Rio)

Allysson Allex Araújo (UFC)

Andrew Beheregarai Finger (UFAL)

Armindo dos Santos de Sousa Teodósio (PUC-MG)

Brunno Fernandes da Silva Gaião (UEPB)

Carlos Enrique Carrasco Gutierrez (UCB)

Dalton Chaves Vilela Júnior (UFAM)

Elionor Farah Jreige Weffort (FECAP)

Gabriel Moreira Campos (UFES)

Guilherme Jonas Costa da Silva (UFU)

Henrique César Muzzio de Paiva Barroso (UFPE)

Jorge de Souza Bispo (UFBA)

Keysa Manuela Cunha de Mascena (UNIFOR)

Manuel Anibal Silva Portugal Vasconcelos Ferreira (UNINOVE)

Marcos Cohen (PUC-Rio)

Marcos Ferreira Santos (La Sabana, Colombia)

Mariluce Paes-de-Souza (UNIR)

Minelle Enéas da Silva (La Rochelle, France)

Pedro Jácome de Moura Jr. (UFPB)

Rafael Fernandes de Mesquita (IFPI)

Rosimeire Pimentel (UFES)

Sonia Maria da Silva Gomes (UFBA)

Susana Jorge (UC, Portugal)

Thiago Henrique Moreira Goes (UFPR)

\section{EDITORIAL BOARD}

Ana Sílvia Rocha Ipiranga (UECE)

Conceição de Maria Pinheiro Barros (UFC)

Danielle Augusto Peres (UFC)

Diego de Queiroz Machado (UFC)

Editinete André da Rocha Garcia (UFC)

Emerson Luís Lemos Marinho (UFC)

Eveline Barbosa Silva Carvalho (UFC)

Fátima Regina Ney Matos (ISMT, Portugal)

Mario Henrique Ogasavara (ESPM)

Paulo Rogério Faustino Matos (UFC)

Rodrigo Bandeira-de-Mello (FGV-EAESP)

Vasco Almeida (ISMT, Portugal)

\section{SCIENTIFIC EDITORIAL BOARD}

Alexandre Reis Graeml (UTFPR)

Augusto Cezar de Aquino Cabral (UFC)

Denise Del Pra Netto Machado (FURB)

Ednilson Bernardes (Georgia Southern University, USA)

Ely Laureano Paiva (FGV-EAESP)

Eugenio Ávila Pedrozo (UFRGS)

Francisco José da Costa (UFPB)

Isak Kruglianskas (FEA-USP)

José Antônio Puppim de Oliveira (UCL)

José Carlos Barbieri (FGV-EAESP)

José Carlos Lázaro da Silva Filho (UFC)

José Célio de Andrade (UFBA)

Luciana Marques Vieira (UNISINOS)

Luciano Barin-Cruz (HEC Montréal, Canada)

Luis Carlos Di Serio (FGV-EAESP)

Marcelle Colares Oliveira (UFC)

Maria Ceci Araujo Misoczky (UFRGS)

Mônica Cavalcanti Sá Abreu (UFC)

Mozar José de Brito (UFL)

Renata Giovinazzo Spers (FEA-USP)

Sandra Maria dos Santos (UFC)

Walter Bataglia (MACKENZIE) 